\title{
IŞKENCE YAPAN KAMU PERSONELINE RÜCU SORUNU
}

\author{
Yrd. Doç. Dr. Türkân Yalçın Sancar \\ Ankara Üniversitesi \\ Hukuk Fakültesi
}

\section{Özet}

9.4.2002 tarihli Resmi Gazete'de yayımlanarak yürürlüğe giren 4748 sayll Kanunun 3. maddesinde, Avrupa Insan Hakları Mahkemesi'nin (AlHM) Türkiye aleyhine Avrupa Insan Haklan Sözleşmesi'nin (AIHS) 3. maddesinde düzenlenen "işkence yasağı" nın ihlali gerekçesiyle vereceği mahkumiyet kararlarından dolayı ödenecek tazminatlar için, işkence yapan kamu personeline rücu edilebileceği hükme bağlanmıştur. Böyle bir düzenleme, ilk bakışta, işkenceyi önleme konusunda ciddi etki doğurabilirmiş ve siyasi iradenin samimiyetinin ifadesiymiş gibi görünmesine rağmen; meseleye biraz daha yakından bakıldığında, söz konusu düzenlemenin bu haliyle ve tek başına işkenceyle mücadeleye katkı sunmasının pek de mümkün olmadığı anlaşlır. Çalışmada, işkence yasağına ilişkin uluslararası ve ulusal genel görünümün ele alındığı bölümlerden sonra, şu anki durumuyla "rücu" kurumunun neden işkenceyi önlemede etkili bir yöntem olamayacağr incelenmekte ve hangi şartlarda etkili olabileceği tartışılmaktadır.

\section{The Problem of Recourse Against the Public Officer for Torture}

\section{Abstract}

This study, discusses the meaning and the value of a regulation which was made in the context of "prevention of torture", constituting one of the obligations that has been undertaken by Turkey with the Accession Partnership Document and National Program within the process of "full membership" beginning with the Helsinki summit held on 10-11 December 1999.

It has been stated in Article 3 of the Act No.4748 which has been promulgated by being published in the Official Journal (dated 9.4.2002) that the right of recourse can be used against the public officer who has tortured, for compensation which will be paid due to European Court of Human Rights' (ECHR) verdict against Turkey because of the violation of "prohibition against torture" which has been provided in Article 3 of European Convention on Human Rights.

Even if this article may at first sight seem to have had a serious effect on preventing torture and been the expression of sincereness of the political will; at a closer look, it can be understood that it cannot be so possible for this regulation itself in its present form to serve as a means for the fight against torture.

In the study, after the chapters focusing on the national and international general view on prohibition of torture, it is discussed why recourse with its present form cannot be an effective way in preventing torture and in which conditions it can be effective. 


\section{İşkence Yapan Kamu Personeline Rücu Sorunu}

\section{GiRiş}

En yaygin ve ağır insan haklan ihlali olan işkence, aynu zamanda söylem ile pratik ve norm ile gerçeklik arasındaki gerilimin, daha doğrusu uçurumun en derin olduğu insan hakları alanlarının başında gelmektedir. Bir defa en baskıcı rejimler bile, işkenceye başvurduklarını reddeder, işkenceyi onaylamadıklarını ısrarla söyler, köşeye sıkıştıkları zamanlarda ise en fazla işkence olaylarının "sistematik" değil, "münferit" olduğunu belirtirler. Oysa uluslararası resmi ve sivil kuruluş ve örgütlerin raporları, dünya devletlerinin büyük bir kısmında yoğun ve sistematik işkence uygulamalarının varlığın ayrıntılarıyla ortaya koyarak, söylem ile eylem arasındaki büyük çatı̧mayı belgelerler.

\section{ULUSLARARASI BELGELER, ULUSAL METINLER VE TŪRKIYE}

Öte yandan işkencenin yasaklanmasına ilişkin kuralların ortaya çıkıs süreci de oldukça uzun sayılabilecek bir geçmişe sahiptir. Bu gelişimi klasik insan haklanı belgeleri sayılan metinler üzerinden kabaca hatrlatmak gerekirse; örneğin 1215 tarihli Magna Carta Libertatum, kişilerin "herhangi bir biçimde kötü muameleye maruz bırakllamayacağı"nı öngören bir hüküm içerir. 1688 tarihli Ingiliz Haklar Belgesi, zalimane ve mutad olmayan cezaların uygulanmasın yasaklayan hükümlere yer verir. 1776 tarihli Virginia Insan Haklan Bildirisi'nin 8., 9. ve 10. maddeleri ile 1789 Fransız Insan ve Yurttaş Haklan Bildirisi'nin 5., 7. ve 9. maddeleri konuyla ilgili hükümler koyar. ${ }^{1}$

Insan haklarınun İkinci Dünya Savaşı'nun ardından uluslararası alana geçişiyle birlikte işkencenin önlenmesini hedefleyen normlar uluslararası belgelerde yer almaya başlar. Bugün uluslararası insan hakları hukukunda global ve bölgesel nitelikli çok sayıda belgede "işkence yasağı"n düzenleyen hükümler bulunduğu gibi, salt bu konuya tahsis edilmiş belgeler de vardır.

1 Bu konuda ayrıntılı bilgi için bkz. (GEMALMAZ, 1990: 36 vd.). 
Uluslararası insan hakları hukukunun doğum belgesi sayılan 1948 tarihli Insan Hakları Evrensel Bildirisi'nin 5. maddesi, işkence yasağın bugün artık geleneksel hale gelmiş genel bir formülle düzenler: "Hiç kimse işkence ya da zalimane, insanlık dışı yahut aşağılayı̊ muamele ya da cezaya maruz bırakılamaz." Bu formül, örneğin 1966 tarihli BM Kişisel ve Siyasal Haklar Sözleşmesi'nin 7. maddesinde, Avrupa İnsan Hakları Sözleşmesi'nin 3. maddesinde, Amerikan Insan Haklan Sözleşmesi'nin 5. maddesinde aynen yer alır.

Işkence yasağını genel bir ifadeyle normlaştıran bu belgeler dışında, doğrudan işkencenin önlenmesine tahsis edilmiş biri global, ikisi bölgesel üç belge daha vardır. Bunlardan global nitelikli olan, 1987'de yürürlüğe giren ve kısaca BM Işkencenin Önlenmesi Sözleşmesi olarak anılan BM Işkence ve Diğer Zalimane, Insanlıkdışı ya da Aşağılayı̇ Muamele ya da Cezanın Önlenmesi Sözleşmesidir. Bölgesel belgelere gelince; bunlardan biri 1989 yllnda yürürlüğe giren Işkence ve Insanlıkdışı ya da Aşağılayıcı Muamele ve Cezanın Önlenmesine lişsin Avrupa Sözleşmesi (kısaca Avrupa İskenceyi Önleme Sözleşmesi); diğeri de 1987 'de yürürlüğe giren Işkencenin Önlenmesi ve Cezalandınlmasına Ilişkin Amerikalılararası Sözleşmedir (kısaca Işkencenin Önlenmesine Hişkin Amerikan Sözleşmesi). ${ }^{2}$

Bu belgeler dışında da, işkenceyi önlemeye yönelik hükümler içeren çeşitli uluslararası metinler vardır. Kısacası, uluslararası hukuk işkence yasağı öngören normlar bakımından epeyce zengindir. Ayrıca bu belgelere taraf olan devletlerin sayısı da yüksek sayılır. Buna rağmen, sonuncusu geçtiğimiz günlerde yayımlanan Uluslararası Af Örgütü'nün raporlan başta olmak üzere, çeşitli kurum ve örgütlerin karar ve raporları, işkencenin dünyada en yaygın insan hakları ihlali olduğunu ortaya koymakta, dolayısıyla norm ile gerçeklik arasındaki uçurumu açığa çıkarmaktadır.

Işkence alanunda söylem ile pratik ve norm ile gerçeklik arasındaki gerilim/uçurum bakımından Türkiye'nin özel ve dikkat çekici örnekler arasında yer aldığı söylenebilir. Başta Avrupa İşkenceyi Önleme Sözleşmesi ile yapılaştırılmış olan Avrupa İskenceyi Önleme Komitesi'nin (CPT) raporlanı olmak üzere ${ }^{3}$ çeşitli uluslararası ve ulusal resmi ve sivil kuruluşun çalışmalarında ${ }^{4}$ Türkiye'de işkencenin yaygın ve sistematik olduğu, olaylar ve belgeler temelinde sergilenmesine ve Avrupa İnsan Hakları Mahkemesi'nden

2 Bu belgelerle ilgili ayrıntılı bilgi için bkz. (GEMALMAZ, 1990: 197 vd.); Insan Haklan Hukukunda Işkence Yasağı, lzmir Barosu Insan Hakları ve Hukuk Araştırmaları Merkezi Yayın, lzmir 1996.

3 Komitenin Türkiye'yle ilgili raporlarına şu ardesten ulaşılabilir: http://www.cpt.coe.int/ en/states/tur.htm

4 Sivil alanda özellikle Türkiye Insan Haklan Vakfinın yıllık ve özel raporlarına bakılabilir (http://www.tihv.org.tr); resmi düzlemde ise bkz. Örneğin, (SEVTMAY, Istanbul: 2001; PIŞKINSÜT, Istanbul: 2001). 
işkence yasağını ihlalden dolayı çok sayıda mahkumiyet kararı çkmasına rağmen, resmi tutum esas olarak işkencenin "münferit" olduğu söylemi üzerine kurulmuştur.

Diğer taraftan işkence yasağına ilişkin kurallar açısından da, hem iki yüzyıla yakın bir geçmiş, hem de gerek doğrudan ulusal normlar, gerekse taraf olunan uluslararası belgelerden oluşan önemli bir külliyat vardır. 1808 tarihli Senedi Ittifak ile 1839 tarihli Tanzimat Fermani'nda yer alan zulüm yasağı, tarihsel sürecin başlangı olarak kabul edilebilir. Iş̧kence ve eziyet yasağı, 1856 tarihli Islahat Ferman ile 1876 tarihli Kanuni Esasi'de açkça düzenlenmiştir. ${ }^{5}$ Cumhuriyet dönemi anayasalannda da bu yasak net bir şekilde yer almiş; TCK'nda işkence ve kötü muamele suç sayllmıştır. Ayrıca Türkiye, işkenceyi önlemeye ilişkin hem BM hem Avrupa sözleşmelerine taraf olmak suretiyle, işkence yasağına ilişkin uluslararası standartlanı ve denetim mekanizmalarının yetkilerini kabul etmiştir. Ancak biraz önce anulan raporlar ve günlük bilgi kaynakları, bazı resmi yetkililerin beyanları, işkence bakımından norm ile gerçeklik arasında derin bir uçurum olduğunu göstermektedir.

\section{AB SÜRECINDE TÜRKIYE}

Türkiye'nin, 10-11 Aralık 1999 tarihli Helsinki zirvesiyle başlayan AB'ne tam üyelik süreci, demokratikleşme ve insan haklarıyla ilgili diğer alanlarda olduğu gibi işkencenin önlenmesi konusunda da yeni bir söylem, norm, pratik ve gerçeklik düzlemine geçmeyi dayatmaktadır. Türkiye'nin $A B$ ile tam üyelik müzakerelerine başlayabilmesi için izlemesi gereken yolu gösteren Katılım Ortaklığı Belgesi, işkence meselesine "siyasi kriterler" bölümünde "kısa vadeli öncelikler" arasında yer vermiştir. Buna göre, Türkiye, "işkenceyle mücadeleye ilişkin hukuki hükümlerin güçlendirilmesi ve gerekli tüm önlemlerin alınmast ve Avrupa Işkencenin Önlenmesi Sözleşmesine riayetin să̆lanmasi" yükümlülüğü altındadır. Türkiye'nin bu belgedeki yükümlülükleri nasıl yerine getireceğine ilişkin vaatlerini içeren Ulusal Program'da "işkenceyle mücadele" konusunda bugüne kadar neler yapıldığı ve bundan sonra neler yapılacağı şu şekilde açıklanmıştır:

"Türk Hükümeti, işkenceyle mücadele konusunda kararlıdır. Bunun için, eğitimden başlayarak işkence olaylarınun aydınlatılması ve sorumlularınin cezalandırilmasina kadar uzanan yasal ve idarî önlemleri güçlendirmiştir.

Bu bağlamda son dönemde alınmış başlıca önlemler şunlardır:

1. Yakalama, Gözaltına Alma ve Ifade Alma Yönetmeliği'nin etkin bir şekilde uygulanması ve uygulamanın sıkı bir biçimde

5 Bu dönemde norm ile pratiğe ilişkin aynntılı bilgi için bkz. (AKÇAM, Istanbul: 1992). 
denetlenmesini sağlamak üzere Haziran 1999'da bir Başbakanlık genelgesi yayımlanmıştr.

2. Ağustos 1999 'da Türk Ceza Kanunu'nun işkence ve kötü muameleyle ilgili maddeleri değiş̧tirilerek, işkence ve kötü muamelenin tanumı uluslararası sözleşmelere uygun şekilde yeniden yapılmış, cezalar artırılmış, ayrica gerçeğe aykurı rapor düzenleyerek işkenceyi gizleyen sağllk personeline cezalar getirilmiştir.

3. Aralık 1999 'da Memurlar ve Diğer Kamu Görevlilerinin Yargılanması Hakkında Kanun kabul edilmiş ve böylece kamu görevlileri hakkında soruşturma ve takibatın süratlendirilmesi mümkün olmuştur.

Buna rağmen ortaya çıan ve Hükümetimiz tarafından hiçbir şekilde müsamaha edilmesi mümkün olmayan işkence ve kötü muamele olaylarınun önlenmesi için, ilgili bakanlıkların yanı sıra, yeni kurulan Başbakanlık Insan Hakları Başkanlığı'na da görev verilmiştir.

Işkence ve kötü muameleyle mücadelenin güçlendirilmesine yönelik bir dizi yasa ve mevzuat değişikliği yapılması planlanmıştır. Bu doğrultuda kısa vadede,

1. Polis Vazife ve Salâhiyet Kanunu ve Tüzüğü, Jandarma Teşkilat, Görev ve Yetkileri Kanunu ve Yönetmeliği, Sahil Güvenlik Komutanlı̆̆ı Kanunu ve Tüzüğü'nün gözden geçirilmesi,

2. Adli Tıp Kurumu'nun modernizasyonu çalışmalarına başlanması öngörülmektedir.

Orta vadede ise,

1. Yeni Türk Ceza Kanunu'nun,

2. Yeni Ceza Muhakemeleri Usulü Kanunu'nun yasalaşması;

3. Insan hakları ihlâllerine meydan verilmemesi için güvenlik güçlerine gerekli eğitimin verilmesi ve ihlâllerin yoğun olarak yaşandiğı ortamların teknolojiden daha fazla yararlanularak etkin denetimi için malî kaynak tahsisi olanaklarınun araşturılması,

4. Işskenceye uğradığı kanitlanan kişiye karşı bu fiili işleyenlerin müşterek ve müteselsil hukukî sorumluluğunun yasa hükmüne bağlanması hedeflenmektedir. "

Bu yazıda, bugüne kadar yapılanların hepsini tek tek ele alıp, işkencenin önlenmesi bakımından ne gibi etkiler doğurabileceklerini irdelemek yerine, Ulusal Program'ın "orta vadeli" işler arasında saydığı ve bir süre önce "uyum paketleri"nden birinde kanunlaştırılan bir düzenleme üzerinde durulacaktır. 


\section{DEVLETiN işKENCE YAPAN PERSONELE RŪCU ETMESi}

TBMM, 26.3.2002 tarihinde "Çeşitli Kanunlarda Değişiklik Yapılmasına Ilişkin Kanun" adını ve 4748 numarasını taşıyan bir "paket"i kabul etti. Bu Kanun, 9.4.2002 tarihli Resmi Gazete'de yayımlanarak yürürlüğe girdi. 4748 saylı Kanunun 3. maddesi, Ulusal Program'in yukarıya aktardığımız "işkenceyle mücadele" kısmınun son saturında yer alan bir taahhüdü gerçekleştirme amacina yönelik bir düzenleme gibi görünmektedir. Düzenleme aynen şöyledir:

"14.7.1965 tarihli ve 657 sayıl Devlet Memurlan Kanununun 13 üncü maddesine birinci fikradan sonra gelmek üzere aşağıdaki fıkra eklenmiştir. Işkence ya da zalimane, gayri insani veya haysiyet krric muamele suçlan nedeniyle Avrupa Insan Haklarn Mahkemesince verilen kararlar sonucunda Devletçe ödenen tazminatlardan dolayı sorumlu personele rücu edilmesi hakkında da yukarıdaki fikra hükmü uygulanir." Burada atıf yaplan "yukaridaki fikra"yı da aktarmak, herhalde bütünü görmek açısından iyi olacaktır: "Kişiler kamu hukukuna tabi görevlerle ilgili olarak uğradıklan zararlardan dolayı bu görevleri yerine get iren personel aleyhine değil, ilgili kurum aleyhine dava açarlar. Ancak, Devlet dairelerine tevdi veya bu dairelerce tahsil veya muhafaza edilen para ve para hükmündeki değerli kağıtlarn ilgili personel tarafindan zimmete geçirilmesi halinde, zimmete geçirilen miktar, cezai takibat sonucu beklenmeden Hazine tarafindan hak sahibine ödenir. Kurumun, genel hükümlere göre sorumlu personele rücu hakkı saklıdır."

\section{V. düzenLemenin etKili olma ihtimali Ve imKanI}

Anlaşıldığı kadarıyla bu düzenleme arachlı̆̆ıla $A B$ organlarına ve kamuoyuna, Avrupa Insan Hakları Mahkemesi'nin (AIHM) Türkiye aleyhine Avrupa Insan Hakları Sözleşmesi'nin (AIHS) 3. maddesinde düzenlenen "işkence yasă̆ı"nın ihlali gerekçesiyle vereceği mahkumiyet kararlarından dolayı ödenecek tazminatların, işkence yapan kamu personelinden tahsil edilmesi yolunu açmak suretiyle, işkence konusunda caydırıc bir etki yaratılacağı mesajı verilmek; böylece siyasi iradenin işkenceyle mücadele niyetinde olduğu gösterilmek istenmektedir. Işkence yapan kamu personeline tazminatlardan dolayı rücu edilmesi fikri, ilk bakışta, işkenceyi önleme konusunda samimi bir niyet ve ciddi bir etki doğurabilirmiş gibi görünür. Ancak soruna hayata geçirilebilirlik imkanları açısından biraz daha yakından bakıldığında durumun pek de öyle olmadığı anlaşılır.

Rücu imkanının doğabilmesi için, AİHM'den başvurucuya/mağdura tazminat ödenmesini de içeren bir mahkumiyet kararının çıkmış olması gerektiğinden, rücu öngören hükmün uygulanabilirliğini öncelikle bu süreç açısından irdelemek; daha sonra da iç hukukta karşllaşlabilecek durumları ve sorunları tarışmak yerinde olur. 


\section{A. AiHM SÜRECi}

Türkiye'nin 1954'ten bu yana taraf olduğu AtHS, içeriğinden çok, ortak güvence sistemine dayanan bir yargısal denetim mekanizması kurması ve bireye sağlanan güvenceyi bir yaptırıma bağlaması dolayısıyla, uluslararası insan haklan hukukunda özel bir yere sahiptir (GÖLCÜKLÜ/GÖZÜBÜYÜK, 1994: 7). Sözleşmeyle getirilen denetim sistemi, iki tür başvuru üzerinden işlemektedir: Sözleşmeye taraf her bir devletin "Sözleşme ve Protokol hükümlerinin başka bir Sözleşmeci Taraf Devlet tarafından ihlal edildiği iddiasıyla Mahkemeye başvurması"na imkan sağlayan "devlet başvurusu" (AİHS m. 33) ve "Sözleşmede ve Protokollerde beyan edilen haklarının bir Sözleşmeci Devlet tarafından ihlal edilmesinden dolayı mağdur olduğunu iddia eden bireylerin, hükümet dışı örgütlerin ve birey topluluklarını" Mahkemeye başvurması imkanın içeren "bireysel başvuru" (AlHS m.34).

AlHM'ne başvuru üzerine başlayan sürecin ayrıntılarına girmek, bu yazının hem iddiasını hem de kapsamını aşar. Bu nedenle burada, sadece sürecin konumuzla ilgili yanları ve özellikleri üzerinde durulacaktur.

\section{Başvuruların Sadece Devlete Karşı Yapılabilmesi}

Öncelikle başvuruların, sadece Sözleşmeye taraf olan devletlere karşı yapılabileceğini belirtelim. Varlığı iddia edilen ihlali gerçekleştiren kamu personeli ya da onun bağlı olduğu kurum, başvuruda davalı olarak gösterilemez. Özel kişilerin eylemlerinden ötürü devletin sorumlu tutulabileceği hallerde de, davalı yine sadece devlet olabilir (TANRIKULU, 2001: 23). Kişilerin taraf olarak gösterildiği başvurular, kişi yönünden yetkisizlik nedeniyle reddedilir (GÖLCÜKLÜ/GÖZÜBÜYÜK, 1994: 53).

\section{2. İ̧ Hukuk Yollarının Tüketilmesi}

AlHM'ne yapılan başvurular, önce kabul edilebilirlik açısından bir incelemeye tabi tutulur. Başvuru kabul edilebilir bulunduktan sonra ancak esas hakkında yargılama yapılır ve Sözleşmenin ihlal edilip edilmediğine karar verilir. Kabul édilebilirlik şartları Sözleşmenin 34. ve 35 . maddelerinde açıklanmıştır. Bunlar arasında, konumuzla en fazla bağlantılı olanı "iç hukuk yollarının tüketilmesi" şartıdır. Bu şartı düzenleyen 35. maddeye göre, "Mahkeme ancak, uluslararası hukukun genellikle tanınmıs kurallarna göre iç hukuktaki bütün başvuru yollan tüketildikten sonra ... önüne getirilen olaylan incelemeye devam edebilir".

Uluslararası kuruluşlara başvurunun iç hukuk yollarını tüketme şartına bağlı olması, uluslararası hukukun temel kurallarındandır. AIHS de, bu kurala 
uygun olarak, kurduğu güvence ve koruma sisteminin ulusal sisteme göre ikincil nitelikte olduğunu göstermek üzere, "iç hukuk yollarınun tüketilmesi"ni başvuruların kabul edilebilirliği açısından şart saymıştır. ${ }^{6}$

Başvurunun kabul edilebilmesi için hangi iç hukuk yollarınun tüketilmesi gerektiğini, her somut olaya göre ayrı ayrı belirlemek gerekir. Ama herhalde ihlalden mağdur olan bireyden, ancak iç hukukta öngörülmüş olan, fiilen ulaşılabilen ve sonuç alma imkanı bulunan, yani etkili olan iç hukuk yollarını tüketmesi beklenir. Başka bir deyişle, iç hukuk yolunun tüketilmiş sayılması için, yapılmış olan haksızlığın düzeltilmesine elverişli olan, etkili ve yeterli başvuru yollanın kullanılması aranır. (GÖLCÜKLÜ/GÖZÜBÜYÜK, 1994: 69).

Iç hukuk yollarını tüketme şartının ayrıntılarını, genel olarak değil de, işkence yasağının ihlali açısından görmekte yarar vardır.

Thlali önlemek veya gidermek bakımından aynı derecede etkili birden fazla iç hukuk yolu varsa, iç hukuk yollarını tüketme şartını yerine getirmiş olmak için bunlardan birini kullanmak yeterlidir. Buna göre, işkence yasağı ihlallerinde tüketilmesi gereken yol, ceza soruşturması ve dava yoludur; idareye karşı tam yargı veya faillere karşı haksız fiil nedeniyle hukuk davası yoluna gidilmesi bu açıdan gerekli değildir. Nitekim AIHM de, işkence yasağının ihlali nedeniyle Türkiye aleyhine yapılan başvurularda, kamu makamlarının (savcının) bilgisine sunulmuş ve bilmesi gereken olaylarda, idari ve medeni iç hukuk yollarına başvurulmamıs olmasını, 35. maddeye aykırı görmemiştir (TANRIKULU, 2001: 48-49).

\section{B. iç HUKUKTA FAiLiN BELIRLENMESi MESELESi}

Avrupa Insan Hakları Mahkemesi'nden, işkence gören mağdura tazminat ödenmesini öngören bir karar çıttğında, bu tazminatı ödeyen devletin "personele rücu" etmek istemesi halinde, çözülmesi gereken en önemli sorun rücu edilecek personelin saptanması olacaktr.

Bir defa AIHM, esas itibariyle failin değil ihlal vak'asının saptanması üzerine kurulmuş bir yargılama süreci içinde karar üretir. Sadece devletin davalı olarak gösterilebilmesi de, Sözleşme sisteminin failden çok ihlale neden olan filin saptanması fikrine dayandığının hem göstergesi hem de olağan sonucudur. Böyle olunca, failin, daha doğrusu rücu edilecek personelin AlHM kararına bakılarak belirlenmesi, çoğu zaman mümkün olmayacaktır. Kaldı ki, aşağıda biraz daha ayrıntıyla değinileceği gibi, AlHM kararında failin kimliğine ilişkin tespitler yer alsa bile, iç hukuktaki ilke ve düzenlemeler nedeniyle, sadece buna dayanarak rücu kurumunu işletmek de sözkonusu olamayabilir.

6 Bu konuda daha fazla bilgi için bkz. (GÖLCÜKLÜ/GÖZÜBÜYÜK, 1994: 68; TANRIKULU, 2001: 47). 
Öte yandan ulusal düzlemde işkence olaylarının çoğunda fiili ve hukuksal nedenlerle fail belirlenememekte, kesinleşmiş mahkumiyet hükümlerinin sayısı son derece sınurh kalmaktadır. Iç hukuk yollarının tüketildiği bir çok durumda bu tüketme genellikle işkence iddialanının idari soruşturmalara takılması veya C.Savcılıklarının takipsizlik kararları vermesi ya da az da olsa mahkemelere intikal etmiş olaylarda beraat kararlarının verilmesi şeklinde olmaktadır. Bu sayllan durumlarda da tazminata mahkum olan devletin rücu edebileceği hiç kimse yoktur. Başka bir deyişle, işkence yapıldığ iddiasıyla karşı karşıya kalan devlet, bu iddianın doğrulanması halinde AfHM'nce tazminat ödemeye mahkum edilecek, fakat işkenceyi yapan personel çeşitli nedenlerle belli olmadığı, daha doğrusu işkence iddiası bir mahkeme kararıyla hükme dönüşmediği için kimseye rücu edemeyecektir.

Burada ele alınan rücu prosedürünün işleyebilmesi için, her şeyden önce ceza mahkemesince verilmiş ve kesinleşmiş bir mahkumiyet kararına intiyaç vardır. Bu bakımdan kısaca hangi aşamalarda iç hukuk yollan tüketilmiş olmasına rağmen failin belli olmadığı noktası üzerinde durulacak ve AlHM'nin kararına hangi aşamada nasıl bir etki tanunursa, getirilen hükmün işlevsel olabileceği hususu tartşllacaktır.

\section{Soruşturma Için Idarenin Izin Vermemesi}

4 Şubat 1339 (1913) tarihli "Memurin Muhakematı Hakkında Kanunu Muvakkat" her zaman tartışma konusu olmuş ${ }^{7}$ ve görevi başında ya da göreviyle ilgili olarak suç işlediği iddia edilen devlet memurları hakkında ceza kovuşturmasının başlatılmasını ve yürütülmesini özel bir usule tabi kıldığı için failleri yargı önüne çıkarmanın ciddi bir engeli olarak ylllarca varlığını sürdürdü. Bu Kanun uzun arayış ve tartışmalardan sonra 4483 Sayılı "Memurlar ve Diğer Kamu Görevlilerinin Yargılanması Hakkında Kanun"un 4 Aralık 1999 tarihli Resmi Gazetede yayımlanmasıyla birlikte yürürlükten kaldırıldı. Yeni Kanun, önceki Kanunda yer alan, memurların yargılanup yargılanmamasına karar verilebilmesi için yapılan "hazırlık soruşturması"nın idarece yürütülmesini öngören sistemi değiştirerek, yerine $C$. Savclarınca yürütülecek hazırlık soruşturması öncesi, bir tür "ön inceleme"ye dayanan idareden "izin alma" yöntemini getirdi. Bu yöntemin de, "idari koruma" konusundaki yaygın uygulamayı esastan değiştirmeye elverişli olduğu söylenemez. ${ }^{8}$

Incelemekte olduğumuz konuya dönecek olursak; işkence iddialarının soruşturulabilmesi için "Memurlar ve Diğer Kamu Görevlilerinin Yargılanması Hakkında Kanun" hükümleri gereğince idareden yargılama izninin alınması gerekir. Bu iznin verilmediği ve iznin verilmemesi kararına karşı ilgili Kanun

7 Tartışmalar için bkz.(ÖZEK, 1961: 35 vd.; SELÇUK, 1997: 127 vd.).

8 lki kanunun ayrıntılı bir karşılaştırması için bkz. (EREN, 2000: 64-78). 
hükümlerine göre itiraz yoluna gidilmediği ya da gidilip de itirazın sonuçsuz kaldığı durumlarda, memur hakkında C. Savclarınca hazırlık soruşturması yapılamaz. Idarenin güvenlik görevlilerini koruma refleksiyle hareket etmesi riskinin her zaman mevcut olduğu da hesaba katıldığında, bu gibi sonuçlarla karşılaşma ihtimalinin hiç de az olmadığı kolayca anlaşılır. Bu durumda işkence gördüğünü iddia eden kişi, iç hukuk yollan tükenmiş olduğundan AtHM'ne başvurabilecektir. AlHM, işkence yasağınun ihlal edildiği sonucuna varır ve ayrıca tazminata hükmederse, devletin ödeyeceği tazminat dolayısıyla kime rücu edeceği konusunda ciddi sorun yaşanacaktur

ÖNERİ: 4483 Sayıl "Memurlar ve Diğer Kamu Görevlilerinin Yargılanması Hakkında Kanun", bu haliyle yürürlükte olduğu sürece, başka bir çok alanda olduğu gibi, rücu meselesinde de işaret edilen tıkanmayı aşmak mümkün olmayacaktr. Bu durumda, köklü çözüm şüphesiz sistemin tümden değiştirilmesi olacaktır. Bunun gerçekleşme ihtimali şu anda gündemde olmadığına göre, işkenceyi önleme ve AlHM'nin verdiği mahkumiyet kararlarından sonra "personele rücu" konusunda getirilen yeni düzenlemenin etkili işlemesi konusunda samimiyetin bir göstergesi olabilecek kısmi değişiklikler yapılabilir. Örneğin, işkence ve kötü muamele iddiaları söz konusu olduğunda "izin" şartın kaldıran biraz daha kapsayıcı bir değişiklik üzerinde durulabilir. Buna da yanaşılmazsa, en azından, AtHM'nin mahkumiyet kararı vermesi halinde, izne gerek olmaksızın C. Savclarının doğrudan doğruya soruşturmaya başlayabilmelerine imkan sağlayan bir değişiklik yapılabilir.

\section{Cumhuriyet Savcılığı'nın Takipsizlik Kararı}

İşkence iddiası ciddi bulunup idarece soruşturma izni verildiğinde olay $\mathrm{C}$. Savcllı̆̆'nun önüne gelecektir. İşkence gördüğünü iddia eden kişi genellikle bunu kanıtlama sorunuyla karşı karşıyadır ve bu son derece zorlu bir süreçtir. Esasen delil ve izlerin işkencenin ortaya çıkmasını engelleyecek şekilde yok edilmesi, sistematik işkence uygulamalarının bilinen bir aşamasını oluşturur. Bu konuda C. Savcllıklarına çok görev düşmekte ve iddiaların titizlikle araştırılması gerekmektedir. CMUK'nun 148. ve 163. maddelerine göre; C. Savcisı "yeterli delil" toplarsa kamu davası açar. İşkence ya da kötü muamele iddiasıyla C. Savalıklarına intikal eden pek çok olay, CMUK'un 164. maddesine göre, yeterli delil bulunmaması ya da keyfiyetin takibe değer görülmemesi nedeniyle "takipsizlik (kovuşturmama) kararı"yla sonuçlanmaktadır. Takipsizlik kararına itiraz edilmediği ve yapilan itiraz da haklı bulunmadığı, yani takipsizlik kararı idari ya da yargisal denetim yollarından birine başvurmak suretiyle kaldırılmadığ ${ }^{9}{ }^{9}$ (CMUK. 165 vd.) takdirde, yine AlHM'ne başvurmak için

9 Kovuşturmama karan ve kovuşturmama kararının ortadan kaldınlması hakkında ayrıntılı bilgi için bkz. (TOROSLU, 1998: 247-248). 
aranan önşartlardan biri olan iç hukuk yolu tüketilmiş olacak ve sonuçta işkence iddiaların ciddiye alan AlHM devletin mahkumiyetine karar verecek olursa, yine personele rücu konusunda sorun yaşanacaktur.

ÖNERI: Iç hukuk yolu C. Savcliğı'nun takipsizlik kararı vermesi ya da takipsizlik kararına yapılan itirazın sonuçsuz kalması üzerine tüketilmiş ve AlHM de iddiayı ciddi bularak devleti tazminata mahkum etmişse hazırlık soruşturmasınun başlatulabilmesi için birkaç çözüm yolu üzerinde düşünülebilir.

C. Savcllı̆ı, AlHM'nin bu kararın "kamu davasının açlabilmesi için yeterli delil" olarak değerlendirebilir. Şayet C. Savcssı harekete geçmiyorsa "idari denetim" mekanizmasında yer alan kurum ve kişiler harekete geçebilirler. Yani Başsavcı, Savcıya kamu davasını açmasını emredebilir veya Adalet Bakanı CMUK'nun 148. maddesinin verdiği yetkiyi kullanarak, C. Savcısına emir verebilir ve bu yolla kamu davasının açılması sağlanabilir. Tabii bu hususların mutlaka açıkça kanuni düzenlemeye konu kılınması ve kamu davasınun açılması ya da açtırılmasının "mecburi yetki" olarak öngörülmesi, takdir yetkisinin kullanımının önüne geçilmesi gerekir

\section{Mahkemenin Beraat Kararı Vermesi}

C. Savcllığ işkencenin varlığı konusunda yeterli delil bulmuşsa kamu davası açar. Yargılama sürecinde de yine ispatla ilgili pek çok hukuki ve fiili sorun yaşanır. Sonuçta mahkeme ya "beraat" kararı verir ya da "mahkumiyet" kararı.

Beraat kararının kesinleşmesi halinde, işkence gördüğünü iđdia eden kişi yine AlHM'ne gidebilir. Eğer Mahkeme devleti tazminat ödemeye mahkum ederse devlet kime ve nasıl rücu edecektir?

Bir defa, kendisine isnat edilen işkence suçundan yargılanup beraat etmiş ve hakkındaki bu karar iç hukuka göre kesinleşmiş kişiye, AlHM kararı dayanak gösterilerek, işkence filinin sorumlusuymuş gibi rücu edilmesi mümkün değildir.

Buna bağlı olarak üzerinde durulması gereken önemli bir nokta vardır ki o da kesin hükmün ${ }^{10}$ sonuçlarından birisi olan "ne (non) bis in idem" ilkesidir. Bu ilkeye göre, aynı fiilden dolayı aynı kişi ancak bir kez kovuşturulabilir. Yani herhangi bir kişi bir fiilden dolayı bir kovuşturmaya maruz kalıp hakkındaki hüküm kesinleştikten sonra, ikinci bir kovuşturmanın yapılması imkansızdır, ${ }^{11}$ kesin hüküm buna engel olur. (CMUK madde 253/3) AtHM'nin tazminata hükmeden kararı, hakkında kesinleşmiş bir beraat kararı bulunan kişi 
bakımından yeni bir davanın açılması sonucunu kendiliğinden doğurmadığına göre, rücu sorunu nasıl çözülecektir?

ÖNERİ: Ceza muhakemesinde çok çeşitli fiili ya da hukuksal yanulgılar nedeniyle yanlıs kararlar verilebilir. ${ }^{12}$ Maddi gerçeği araştran ceza muhakemesinde kesin hükmün otoritesine rağmen, önemli hataların giderilmesine imkan sağlayan bir yol olarak "muhakemenin yenilenmesi" kurumu oluşturulmuştur. Işte AlHM'nin kararı, beraat eden kişinin aleyhine muhakemenin yenilenmesi sebebi olarak değerlendirilebilir. Bu noktada elbette bir takım güçlükler yaşanabilir. AtHM kişileri değil devleti mahkum ettiği ve bu kararlarda işkenceyi yapan kişi ya da kişilerle ilgili bir tespit çoğu kez mümkün olmadığı için, daha önce muhakeme yapılıp da hakkında beraat kararı verilen kişi gerçekten de suçun faili olmayabilir. Bu anlamda AIIHM'nin kararının fiili bir etkisi ortaya çıkmayabilir. Ancak eğer beraat kararı, fail olarak gösterilen kişinin kesin olarak suçun faili olmaması nedeniyle değil de, örneğin yeterli delil bulunamadığı için verilmişse ve bu noktada tereddütler yaşanmış ve şüphe sanık lehine yorumlanmıssa o zaman AIHM'nin karan muhakemenin yenilenmesinde önem taşıyabilir. Bu arada ceza muhakemesinde kesin delilin söz konusu olamayacağını ve AlHM kararının yenilenen muhakemede kesin delil olarak kullanulip yargılama sonucunun mutlaka mahkumiyetle sonuçlandırılmayabileceğini de gözden uzak tutmamak gerekir. Çünkü ceza muhakemesinde amaç, suç teşkil eden bir fiile mutlaka bir fail bulmak değil, suçun failini bulmaktır.

Işkence iddialarının mahkumiyetle sonuçlanması durumunda da, cezanın yetersiz bulunması, fiilin "işkence" değil, "kötü muamele" olarak nitelendirilmesi gibi çeşitli gerekçelerle AIHM'ne gitmek mümkündür. Bu durumda verilen tazminat kararıyla ilgili olarak, personele rücu etme konusunda hukuksal bir sorun yaşanmayacakttr. Önemli olan iddia edilen fiilin gerçekleştirildiğinin mahkemece saptanmasıdır. Yoksa mahkemenin fiili vasıflandırışıla AlHM'nin vasıflandırısıı arasında bir fark olmasını, yani AİHM'nin "işkence" dediğine mahkemenin "kötü muamele" demiş olmasının hiçbir önemi yoktur.

\section{Dava Zamanaşımı Medeniyle Takipsizlik Ya Da Düşme Kararı Verilmesi}

Zamanaşımı, devletin, suçun işlenmesinin üzerinden belli bir süre geçmesi durumunda davaya devam etmemeyi ya da kesinleşen cezanin belli sürelerde infaz edilememesi nedeniyle cezalandırmaktan vazgeçmeyi önceden kabul etmesi demektir. Zamanaşımınun davayı düşüren türüne dava zamanaşımı, cezanın infazını engelleyen türüne ise ceza zamanaşımı denir 
(CENTEL, 2001: 658). ${ }^{13}$ Dava zamanaşımı belli sürenin geçmesi nedeniyle kamu davasının açılamaması veya açılmışsa davaya devam olunmayarak düşürülmesi sonucunu doğuran zamanaşımıdır (CENTEL, 2001: 659).

Suçlañn ve cezaların, belli koşullarla zamanaşımına uğramalan genel bir kuraldır; yani tüm suçlar için zamanaşımı söz konusudur. Dava zamanaşımı süreleri TCK'nun 102. maddesinde düzenlenmiştir. ${ }^{14}$ Fakat 102. maddenin son fikrasına ve 118. maddesine göre; TCK'nun ikinci kitabının birinci babında yer alan, yani devletin şahsiyetine karşı işlenen bir suç (m.125-173) ; ölüm, müebbet ya da geçici ağır hapis cezasını gerektiriyorsa ve yurt dışında işlenmişse dava ve ceza zamanaşımı işlemez.

Türkiye, aralarında "Işkenceye ve Diğer Zalimane, Insanlıkdışı ve Onur Kırıcı Muamele ya da Cezaya Karşı Birleşmiş Milletler Sözleşmesi" (İşkenceye Karşı Sözleşme $)^{15}$ ve bu alandaki bir çok Sözleşmeye ${ }^{16}$ taraf olmasına rağmen, işkence suçunun tanımı, 1999 yulında TCK'nun 243. maddesinde yapılan değişiklikle de yaygın ve yerleşik anlamınu karşılayacak hale getirilmemiştir. ${ }^{17}$

13 Zamanaşımının lehinde ve aleyhindeki düşünceler için aynca bkz. (DÖNMEZER/ ERMAN, 1994: $241 \mathrm{vd}$.).

14 TCK'nun 102. maddesi şöyledir: "Kanunda başka türlü yazılmamış olan ahoalin maadasında hukuku amme dazast:

1. Olüm ve mülebbet ağır hapis cezalarını müstelzim cuikümlerde yirmi sene,

2. Yirmi seneden aşă̆ı olmamak üzere muvakkat ă̆ır hapis cezasını müstelzim cürümlerde onbeş sene,

3. Beş seneden ziyade ve yirmi seneden az ağır hapis veya beş seneden ziyade hapis yahut hidematı ammeden müebbeden mahrumiyet cezalarından birini müstelzim cürümlerde on sene,

4. Beş seneden ziyade olmamak üzere ağır hapis veya hidematı ammeden muoakkaten mahrumiyet cezalartnı ve ă̆ır para cezastnt müstelzim cürümlerde beş sene,

5. Bir aydan ziyade hafif hapis veya otuz (1999/4421 tarih ve sayzlt Kanunla 23580 misli artinldi) liradan ziyade hafif para cezastnı müstelzim fillerde iki sene,

6. Bundan eovelki bentlerde beyan olunan miktardan aşă̆ı cezaları müstelzim kabahatlerde altı ay geçmesi ile ortadan kalkar.

Bu kanunun ikinci kitabmın birinci babmda yaztl ölüm veya muðakkat ağır hapis cezalarını müstelzim cürümlerin yurt dısııda işlenmesi halinde dava müruru zamant yoktur."

15 Işkenceye Karşı Sözleşme'nin 1. maddesi şöyledir: "Bu Sözleşme'nin amaçlan bakımından 'işkence' terimi, bir kişiye kendisinden ya da üçüncü bir kişiden bir bilgi ya da itiraf elde etmek, kendisinin ya da ǔçünü bir kişinin işlemiş olduğu ya da işlediğinden kuşku duyulan bir eylemden dolayı onu cezalandırmak, kendisine ya da üçüncü bir kişiye gözdă̆ı oermek ya da onlart zorlamak maksadıyla ya da ayrtmcilı̆ga dayalı herhangi bir nedenle bir resmi göreoli ya da resmi sıfatla hareket eden bir başkası tarafindan ya da onun teşoik etmesi ya da onayı ya da izni ile bilerek maddi ya da maneoi act vermek ya da eziyet etmektir."

16 Türkiye'nin imzaladığı sözleşmeler arasında; BM Çocuk Haklan Bildirgesi, Kadınlara Karşı Her Türlü Ayrımcilığın Kaldırılması Üzerine BM Sözleşmesi, Insan Hakları ve Temel Özgürlüklerin Korunması Üzerine Avrupa Sözleşmesi, Işkencenin Önlenmesi Üzerine Avrupa Sözleşmesi de vardır.

17 TCK'nun 243. maddesinin değişiklikten önceki biçimi şöyleydi: "Mahkemeler ve meclisler reis ve azalartndan ve sair hükümet memurlarından biri maznun bulunan kimselerin cürümlerinin söyletmek için işkence eder yahut zalimane veya gayrinsani veya haysiyet kurıcı muamelelere başvurursa bes seneye kadar ă̆ır hapis ve müebbeden veya muvakkaten memuriyetten mahrumiyet cezası ile mahkum olur." 
Işkencenin tanumunun ceza kanunumuzda tatmin edici bir biçimde yapılmamış olması nedeniyle de uygulamada işkence sayılması gereken pek çok olay, C. Savcisı ya da mahkemeler ve hatta Yargitay tarafından vasıflandırilurken çoğu zaman 243. maddeye göre "işkence" olarak değil de 245. maddeye göre ${ }^{18}$ "kötü muamele"19 olarak değerlendirilmektedir. Bu durum, diğer pek çok olumsuzluğun yanında, dava zamanaşımı sürelerinin hesaplanmasında da farklılıklar yaratmaktadır. TCK'nun 243. maddesinde yer alan işkence suçunun dava zamanaşımı süresi 10 yıl iken, 245. maddede yer alan kötü muamele suçunun dava zamanaşımı süresi 5 yıldır. Işkence iddialarının konu olduğu soruşturma ya da davaların zamanaşımına uğrama riskleri, diğer olaylara nazaran daha yüksektir. Çeşitli nedenlerle işkence iddialarının ilgili makamlara duyurulmasında yaşanan fiili ve hukuksal güçlükler, işkence mağdurlarının işkenceye maruz kaldıklarını uzun süre dile getirememeleri, soruşturma ve muhakeme aşamasında yaşanan ispat güçlükleri, ilgili kurum ve organların bu iddiaları takip etme konusundaki yavaşlıkları ve isteksizlikleri, mahkemelerin özellikle güvenlik birimleri ve Adli Tip Kurumu ile yaptıklan uzun yazışmalar, son soruşturma aşamasında duruşmalar arasındaki sürelerin çok uzun olması, muhakemelerin nakledilmesi olaylarınun sıklığ 1 karşısında pek çok işkence ya da kötü muamele olayı dava zamanaşımına uğrayabilmektedir. Bu yavaşlık ve isteksizlik karşısında, dava zamanaşımının durmasını (TCK. md. 107) ya da kesilmesini (TCK. md. 104) sağlayan sebepler de çoğu zaman bu sonucu yani dava zamanaşımı süresinin dolmasını önleyemeyecektir. ${ }^{20}$

Bu maddenin 1999 değişikliğinden sonra ve günümüzdeki hali ise şöyledir: "Bir kimseye cürümlerini söyletmek, mağdurun, şahsi davacının, davaya kattlan kimsenin veya bir tantğın olayları bildirmesini engellemek, sikayet veya ihbarda bulunmast veya tantklik etmesi sebebiyle veya diğer herhangi bir sebeple işkence eden veya zalimane veya gayrinsani veya haysiyet ktrict muamelelere başouran memur veya diğer kamu göreolilerine sekiz yıla kadar ağır hapis ve sürekli veya geçici olarak kamu hizmetlerinden mahrumiyet cezast verilir."

18 TCK'nun 245. maddesi şöyledir: "Kuvvei cebriye imaline memur olanlar ve bilumum zabıta ve ihzar memurlart, memuriyetlerinin icrada ve mafeokinde bulunan amirin emrini infazda kanun ve nizamin tayin ettiği ahoalden başka surette bir kimse hakkında suimuamele veya cismen eza verecek hale cüret eder yahut o kimseyi darp ve cerh eylerse üç aydan beş seneye kadar hapis ve muvakkaten memuriyetten mahrumiyet cezalart ile cezalandırlır. Ĕ̈er işlediği curüm bu fiillerin feokinde ise 0 cürümlere terettüp eden ceza üçte birden yartya kadar artırllir."

19 Işkence suçu kavramı ve benzer suçlardan farkı konusunda ayrıntılı bilgi için bkz. (DEMIRBAŞ, 1992: 5-8).

20 Davanın yürütülmesine engel olan belli nedenler ortaya çıktı̆ında, bunların sonuçlanmasına kadar zamanaşımı süresi işlemez. Buna daøa zamanaşımının durması denir. Durma nedeni ortadan kalktı̆̆ında, süre kaldığı yerden işlemeye devam eder. Kamu davasının açılmasının izne bağlı olması, kamu davası açı̀masının karar alınmasına bağlı olması, bekletici mesele bulunması, milletvekilliği sıfatının bulunması gibi nedenler durma nedenleridir.

Dava zamanaşımını kesilmesi ise, ceza soruşturmasına ilişkin belli işlemlerin yapılması nedeniyle, o ana kadar işlenmiş sürenin işlememiş sayılmasıdır. Söz konusu işlemin yapılmasıyla birlikte süre yeniden yani kaldığı yerden değil, baştan itibaren işlemeye başlayacaktır. Kesilme nedenleri; mahkumiyet kararı verilmesi, yakalama müzekkeresi, tutuklama müzekkeresi, celp müzekkeresi, ihzar müzekkeresi, sanığın sorguya çekilmesi, 
TCK'nun birinci kitabinin dokuzuncu babinda "dava ve cezanın sukutu" başlığı altında yer alan dava zamanaşımının bulunması halinde, Savcliklar ve mahkemeler tıpkı bir muhakeme şartını gerçekleşmemiş olması nedeniyle hangi kararları verebiliyorlarsa, o kararlar vereceklerdir; ${ }^{21}$ yani savclliklar kovuşturmama kararı verebilecekleri gibi mahkemeler de, (Yargitay dahil) "dava zamanaşımı" nedeniyle düşme karan verebilirler. Bu durumlarla işkence ve kötü muamele suçlan bağlamında ülkemiz pratiğinde sıç̧a karşılaşılmaktadır. Bu şekilde dava zamanaşımına uğramış bir işkence olayının, AtHM'nde değerlendirilerek sonuçta mahkumiyet kararı verilmesi durumunda, yine kesinleşmiş bir hükümle suçu işlediği sabit olan bir kişi bulunmadiğından, tazminatı ödeyen devletin rücu imkan da olmayacaktır.

ÖNERİ: Tabii ki ilk olarak söylenmesi gereken husus tüm davalarda gösterilmesi gereken hassasiyetin bu davalarda da gösterilmesi, soruşturmaları uzatabilecek mảksatlı ya da maksatsız uygulamalardan vazgeçilmesidir.

Bununla beraber, alınabilecek özel tedbirler arasında, işkence suçunun tanımının uluslararası sözleşmelere uygun biçimde yapılması gereğine işaret edilebilir. Böylece işkence sayılan pek çok eylemin "kötü muamele" olarak değerlendirilmesinin ve zamanaşımı süresinin kısaltılmasının önüne geçilebilir.

Gerçekleştirilebilirliği konusunda çok büyük tereddütlerimiz olmakla birlikte bir diğer önerimiz, en yaygın insan hakkı ihlali olarak ortaya çkan işkence suçunun zamanaşımına uğramaması ve yasadaki istisnalar arasında yer almasıdur.

\section{DEĞERLENDiRME}

Görüldüğü gibi iç hukuk yollarınun tüketildiği bir çok durumda, devletin tazminat ödemeye mahkum edilmiş olması halinde, yasa ile güdülen amaç gerçekleşmeyecek ve rücu imkanı olmayacaktır. Bu düzenleme elbette ki önemlidir; ancak işkence olaylarının önüne geçmek konusunda siyasi iradenin samimiyetine inandırıcılık kazandırılabilmesi için, işkencenin önlenmesine dönük başka tedbirlerin gerekliliğini ve önemini gözden kaçırmadan, rücu kurumunun da gerçekten ve etkili bir şekilde işlemesini sağlayacak düzenlemelerin yapılmasına ihtiyaç vardır. Lakin bütün bunların önünde ve ötesinde, işkencenin önlenmesinde en önemli faktörün kararl ve samimi bir siyasi iradenin varlığını sürekli ve etkili biçimde sergilemek olduğunu akıldan çıarmamak gerekir.

son soruşturma açılması kararı, iddianame yazılmasıdır. Dava zamanaşımını durduran ve kesen sebepler hakkında ayrıntılı bilgi için bkz. (CENTEL, 2001: 663-671).

21 Suçlunun cezalandırılmasına tesir eden sebep ve muhakeme şartı arasındaki benzerlikler ve ceza muhakemesi şartlannın sonuçlan hakkında ayrıntılı bilgi için bkz. (KUNTER/YENISEY, 1998: 69-79). 
Amacı maddi gerçeği bulmak olan ceza muhakemesi hukukunda, bu amaca ulaşmak için her yol kullanulamaz. Her yolun kullanulabileceğini söylemek, bir delil bulma ya da delil yaratma yöntemi olarak işkencenin meşru ya da mübah görülmesi sonucunu doğurur. Ceza muhakemesinde delil elde etmede kullanulabilecek yöntemler sadece adli ya da hukuksal niteliğe sahip olanlardır. Hukuka aykurı yöntemlerle elde edilen bilgilerin hiçbir delil değeri yoktur. Bu husus yasalarda da açikça ifadesini bulmuş olmasına rağmen, ${ }^{22}$ pratikte bu ilkenin gereklerinin hakkıyla yerini getirildiğini söylemek mümkün değildir. Isşkenceyle mücadele konusunda samimi bir yaklaşım, işkence yapanın bu faaliyeti sonucu elde ettiğini düşündüğü verilere hiçbir hukuksal değer tanınmamayı gerektirir. Işkence yaparak elde edilen itirafın ya da bilginin kullanıldığın, bunlara delil değeri atfedildiğini gören bir kişi işkence yapmaya devam edecektir. Yaptığı işin devlet menfaatine olduğuna inanan ya da inandırılan, önüne gelenin işkenceyi hak ettiğini düşünen ve işkence yapsa da bir tür dokunulmazlık zırhından yararlanacağı kanaatinde olan bir görevlinin işkenceden vazgeçmesi mümkün değildir.

Bu yazıda ele aldığımız düzenlemeyi işkenceyi önleme konusunda etkili bir tedbir olarak değerlendirmek, yukarıda sergilemeye çalıştığımız nedenlerle, mümkün değildir. Bunlara ilaveten, "personele rücu" konusunda zaten bir zorunluluk da getirilmemiş, sadece kurumun "rücu hakkının saklı" olduğu belirtilmiştir. Oysa Anayasa'nın ilgili hükmü (m.129/5) ${ }^{23}$ dikkate alındığında, bu konuda kuruma bir takdir yetkisi verilmemesi, rücu etmenin zorunlu hale getirilmesi gerekirdi.

Ayrıca söz konusu hüküm ilk bakışta sadece 657 sayılı Devlet Memurları Kanunu'na tabi olan personelle ilgiliymiş gibi görünmektedir. Uygulamada daha geniş anlaşılması arzu edilir; fakat uygulama bu yönde gelişmediği takdirde 24657 Saylı Devlet Memurlan Kanunu'na tabi olmayan kamu görevlilerine, işkence yüzünden ödenecek tazminatlar için bu Kanuna göre rücu edilmesinde sorun yaşanabilir. TCK'nun 243. maddesi "memur veya diğer kamu görevlileri"nden söz etmektedir. Olası farklı yorum ve uygulamayı önelemek için; tüm memurların ve diğer kamu görevlilerinin işkence suçu kapsamındaki

22 Ayruntılı bilgi için bkz. (SAHIN, 1997: 31 vd.; KAYMAZ, 1997: 86 vd.).

23 Anayasa'nın 129. maddesinin 5. fikrası şöyledir: "Memurlar ve diğer kamu göreolilerinin yetkilerini kullanırken işledikleri kusurlardan doğan tazminat dazaları, kendilerine rücu edilmek kaydıyla ve kanunun gösterdiği şekil ve şartlara uygun olarak, ancak idare aleyhine açılabilir."

24 "Kolluk, genel ve özel kolluk olarak ikiye aynlır. Genel kolluk polis ve jandarmadan meydana gelir. Özel kolluk ise, genel kolluk dı̧ında kalan ve özel kanunlarına göre kurulup belli kolluk hizmetlerini yerine getiren kuvvetlerdir. Genel kolluk yaptığı görev itibariyle suç öncesi ve suç kolluğu bölümlerine ayrılır. Suç kolluğu suç işlendikten sonrası için, suç ve suçlulann araştırılması yönünde görev yapar. Ancak ülkemizde henüz ayn bir suç kolluğu teşkilatı bulunmadı̆̆ından, bu görevi de polis ve jandarma yerine getirmektedir." (\$AHIN, 1997: 65-66). 
eylemlerinden doğan zararlar nedeniyle, AIHM tarafından verilen mahkumiyet kararlarından dolayı ödenen tazminatların, rücu kapsamında olacağını öngören daha kapsayıcı bir hüküm amaca daha uygun olurdu.

\section{Kaynakça}

AKÇAM, Taner (1992), Siyasi Kültürümüzde Zulüm ve Işkence (Istanbul :lietısim Yay.).

CENTEL, Nur (2001), Türk Ceza Hukukuna Giriş (lstanbul: Beta Yayıncılık).

DEMIRBAȘ, TImur (1992), Türk Ceza Hukukunda lşkence Suçu (Ankara: Dokuz Eylül Oniversites] Hukuk Fak. Yay.).

EREN, Abdurrahman (2000), Memurin Muhakemat Hakkında Kanunu Muvakkat lle Onu Yūrülükten Kaidıran Mernurlar ve Diger Kamu Görevililerinin Yargılanması Hakkında Kanunun Karşılaştınıması," Ankara Oniversitesi Siyasal Bilgiler Fakültesi Dergisi (Yıl 55, Sayı 3): 55-78.

DŌNMEZER, Sulhl/ ERMAN, Sahir (1994), Nazari ve Tatbiki Ceza Hukuku, Genel Kısım, C.III (lstanbul: Beta Basım Yayım, 10. Baskı).

EREM, Faruk (1986) Ceza Yargılaması Hukuku (Ankara: Işın Yayıncılık, 6. Baskı).

GEMALMAZ, Mehmet Semih (1990), Cllusalüstü Insan Haklan Hukukunda Işkencenin Onlenmesi (Amaç Yayıncilık).

GÓLCUKLO, Feyyaz / GÖzÖBÜYÖK, Şeref (1994). Aurupa Insan Haklan Sözleşmesi ve Uygulaması (Ankara).

KAYMAZ, Seydi (1997), Ceza Muhakemesinde Hukuka Aykin (Yasak) Deliller (Ankara: Seçkin Yayınev1).

KUNTER, Nurullah / YENISEY, Feridun (1998), Ceza Muhakemesi Hukuku (lstanbul: Beta Basım Yayım, 10. Baskı).

ÖZEK, Cetin (1961), "Türk Hukukunda Memurların Muhakemesi," Istanbul Oniversitesi Hukuk Fakültesi Mecmuası (Cilt: VI, Sayı: 1-4): 34-85.

ÖZGEN, Eralp (1968), Ceza Muhakemesinin Yenilenmesi (Ankara: Başnur Matbaası).

PIŞKINSŬT, Sema (2001), Filistin Askısından Fezlekeye Işkencenin Kitabı (Istanbul: Bılgi Yayınevl).

SELÇK, Sami (1997), Memur Yargılaması Hakkında (Istanbul: TÖSlAD Yayınlan, No. T/97-209).

SEVIMAY, Devrim (2001), TBMM Insan Haklan Komisyonu Raporlannda Resmen Işkence (lstanbul: Metis Yayınları).

SAHIN, Cumhur (1994), Sanığın Kolluk Tarafindan Sorgulanması (Ankara: Yetki).

TANRIKULU, M. Sezgin (2001), Insan Haklan Aurupa Mahkemesine Bireysel Başuuru Ķ̧in El Kitabı (Istanbul: Istanbul Barosu CMUK Uygulama Servisj Yayını).

TOROSLU, Nevzat (1998), Ceza Muhakemesi Hukuku (Ankara: Savaş Yayınevi).

YURTCAN, Erdener (1987), Kesin Hükmün Ceza Muhakemesini Önleme Etkisi (Istanbul: Istanbul Onjversitesi Hukuk Fakültesi Yayını). 